\title{
Article \\ Effects of Melatonin Treatment on Sweet Cherry Tree Yield and Fruit Quality
}

\author{
Alberto Carrión-Antolí ${ }^{1}$, José Manuel Lorente-Mento ${ }^{2}$, Juan Miguel Valverde ${ }^{1} \mathbb{D}$, Salvador Castillo ${ }^{1}$, \\ Daniel Valero ${ }^{1, *}$ (i) and María Serrano ${ }^{2}$ (i)
}

1 Department of Food Technology, Escuela Politécnica Superior de Orihuela, University Miguel Hernández, Ctra. Beniel km. 3.2, 03312 Alicante, Spain; alberto.antoli@umh.es (A.C.-A.); jm.valverde@umh.es (J.M.V.); scastillo@umh.es (S.C.)

2 Department of Applied Biology, Escuela Politécnica Superior de Orihuela, University Miguel Hernández, Ctra. Beniel km. 3.2, 03312 Alicante, Spain; j.lorente@umh.es (J.M.L.-M.); m.serrano@umh.es (M.S.)

* Correspondence: daniel.valero@umh.es; Tel.: +34-966-749-743

check for

updates

Citation: Carrión-Antolí, A.;

Lorente-Mento, J.M.; Valverde, J.M.; Castillo, S.; Valero, D.; Serrano, M. Effects of Melatonin Treatment on Sweet Cherry Tree Yield and Fruit Quality. Agronomy 2022, 12, 3. https://doi.org/10.3390/ agronomy 12010003

Academic Editors: Vasileios Ziogas and Konstantinos Papoutsis

Received: 29 November 2021 Accepted: 16 December 2021 Published: 22 December 2021

Publisher's Note: MDPI stays neutral with regard to jurisdictional claims in published maps and institutional affiliations.

Copyright: (C) 2021 by the authors. Licensee MDPI, Basel, Switzerland. This article is an open access article distributed under the terms and conditions of the Creative Commons Attribution (CC BY) license (https:// creativecommons.org/licenses/by/ $4.0 /)$.

\begin{abstract}
The effects of preharvest melatonin treatment, applied as foliar spray at $0.1,0.3$ and $0.5 \mathrm{mM}$ concentration at three key points of fruit development (pit hardening, initial colour changes and 3 days before harvesting), on crop yield and fruit quality properties at harvest was evaluated in three sweet cherry cultivars, 'Prime Giant', 'Lapins' and 'Sweet Heart', and two years, 2019 and 2020. The results showed that melatonin treatment had no effect on crop yield, except for the 'Lapins' cultivar, in which increases were found. However, decayed and cracked fruit percentage was decreased in all cultivars in 2020 when adverse weather conditions occurred and commercial crop yield was increased, especially for $0.3 \mathrm{mM}$ dose. Fruit quality traits at harvest, such as fruit weight, colour, firmness, total soluble solids and titratable acidity, were enhanced by melatonin treatments in all sweet cherry cultivars and in both years. Moreover, bioactive compounds, such as total phenolics and total and individual anthocyanins, were also found at higher levels in fruit from melatonin-treated trees with respect to controls. Thus, taking into account all these effects, $0.3 \mathrm{mM}$ melatonin foliar spray, at three key points of fruit developmental stages, could be a useful tool to improve crop yield and quality traits of sweet cherries, especially their content on bioactive compounds with antioxidant properties and health beneficial effects.
\end{abstract}

Keywords: Prunus avium; yield; firmness; acidity; soluble solids; phenolics; anthocyanins

\section{Introduction}

Sweet cherry fruit (Prunus avium L.) is highly valued by consumers worldwide due to its excellent quality properties, mainly its colour, sugar and organic acid content, flavour, texture and juiciness [1-3]. In addition, sweet cherry fruit are rich in bioactive compounds, namely phenolics (including anthocyanins) and ascorbic acid, which are responsible of the health benefit effects attributed to sweet cherry consumption, the major ones being antimicrobial, antidiabetic, anticancer and anti-inflammatory effects, as well as neuroprotection and cardiovascular protection activity [4-6]. According to FAOSTAT [7], Spain is the sixth largest sweet cherry producing country in the world, with 118,380 tons, after Turkey, the USA, Chile, Uzbekistan and Iran.

Melatonin was identified in 1995 in plants from mono- and dicotyledonous species [8], and since then, its effect on regulating a wide range of plant physiological processes, from seed germination to fruit maturation and senescence, as well as on inducing plant resistance to biotic and abiotic stresses, has been reported in a wide range of plant species $[9,10]$. In addition, recent reports have shown a role of melatonin on regulating fruit ripening, although most of them have been focused on postharvest treatments [11,12]. However, the effect of pre-harvest melatonin treatments on on-tree fruit ripening and quality traits at harvest has been evaluated in very few papers, and different effects have been reported 
depending on fruit species, concentration or application time. Thus, the application of $0.1 \mathrm{mM}$ melatonin to tomato plants in the irrigation system increased lycopene and sugar content in fruits showing an acceleration of fruit ripening [13]. However, melatonin foliar spray treatment of apricot trees increased crop yield and fruit weight, but no effect on fruit on-tree ripening was observed [14]. In addition, enhanced apricot quality parameters at harvest and maintenance during storage, at chilling and not-chilling temperatures, have recently been reported in apricot fruits from melatonin-treated trees [15]. Accordingly, melatonin treatment of 'Mollar de Elche' pomegranate trees increased fruit quality traits at harvest, including anthocyanin and phenolic content, and overall fruit quality was maintained during storage at higher levels as compared with fruit from control trees [16].

Specifically, in sweet cherry, it has been recently reported that postharvest melatonin treatments, by dipping in $0.05-1.0 \mathrm{mM}$ melatonin solutions for $5 \mathrm{~min}$, delayed senescence and maintained fruit quality during storage in some sweet cherry cultivars, such as 'Siah Mashhad' [17], 'Sunburst' [18], 'Santina' and Royal Rainier' [19]. On the other hand, melatonin $(0.01$ and $0.1 \mathrm{mM})$ applied directly to fruit surface at stage II of development (green and large in size fruit) delayed fruit ripening, manifested by delayed anthocyanin accumulation, in the 'Prime Giant' cultivar [20]. On the contrary, foliar spray of sweet cherry 'Ferrovia' with $0.5 \mathrm{mM}$ melatonin 2 and 1 weeks prior to harvest led to fruit with a higher content of the individual anthocyanins cyaniding 3-rutinoside, cyaniding 3-galactoside and cyaniding 3-glucoside at harvest, showing an acceleration of the fruit ripening process [21]. However, as far as we know, no literature is available regarding the effect of pre-harvest melatonin treatment on sweet cherry tree yield or fruit quality properties at harvest. Thus, the aim of the present experiment was to evaluate the effects of foliar spray of sweet cherry trees with melatonin on yield and on fruit quality and nutritional and functional properties at harvest on three cultivars and two experimental years.

\section{Materials and Methods}

\subsection{Plant Material and Experimental Design}

Experiments were performed in a commercial field plot located at Jumilla (Murcia, Spain, UTMX: 463.700 UTMY: 4.268.900) with sweet cherry trees (Prunus avium L.) of cultivars 'Prime Giant' and 'Lapins' in 2019 and 2020. In addition, the 'Sweet Heart' cultivar was also assayed in 2020. 'Prime Giant' and 'Lapins' cultivars were planted in January 2012 and 'Sweet Heart' in January 2015 and all of them grafted onto SL-64 rootstock. Climatic conditions in the crop field were: mean annual temperatures 15.24 and $15.30{ }^{\circ} \mathrm{C}$ for 2019 and 2020, respectively, and an accumulated rainfall of 357 and $352 \mathrm{~mm}$ for 2019 and 2020, respectively. Sweet cherry trees were under similar agronomic practices for both years with 60:30:100 $\mathrm{kg} \mathrm{ha}^{-1} \mathrm{~N}: \mathrm{P}: \mathrm{K}$ fertilisation and open-centre pruning. Melatonin treatments were performed by applying $3 \mathrm{~L}$ per tree (with a manual sprayer machine) of freshly prepared melatonin solutions at $0.1,0.3$ and $0.5 \mathrm{mM}$ containing $1 \mathrm{~mL} \mathrm{~L}^{-1}$ Tween. Similarly, $3 \mathrm{~L}$ of distilled water with $1 \mathrm{~mL} \mathrm{~L}^{-1}$ Tween were applied to control trees. For each treatment and cultivar, three replicates of three trees were used. Each treatment was repeated three times, at pit hardening, at the beginning of colour changes and 3 days before harvest (Table 1). Sweet cherries were harvested at commercial ripening stage, according to commercial practices, based on the characteristic skin colour of each cultivar. Total yield per tree was recorded as $\mathrm{kg}_{\text {tree }}-1$ and a sample of 100 fruit per tree was taken at random and weighed to obtain data of fruit weight average. Lots for each replicate were mixed and transported to laboratory in $3 \mathrm{~h}$. Then, 3 lots of 20 fruits, homogenous in size and colour and without visual defects, were taken at random from each field replicate and treatment and used for the following analytical measures. 
Table 1. Dates for treatments (T1, T2 and T3) and harvest date in the 2019 and 2020 experiments.

\begin{tabular}{cccccc}
\hline Year & Cultivar & T1 & T2 & T3 & Harvest \\
\hline \multirow{2}{*}{2019} & 'Prime Giant' & 4 May & 22 May & 8 June & 11 June \\
& 'Lapins' & 5 May & 1 June & 17 June & 21 June \\
\hline \multirow{2}{*}{2020} & 'Prime Giant' & 23 April & 15 May & 30 May & 4 June \\
& 'Lapins' & 24 April & 26 May & 13 June & 17 June \\
& 'Sweet heart' & 28 April & 1 June & 27 June & 2 July \\
\hline
\end{tabular}

\subsection{Quality Parameters}

Colour was measured independently in each fruit with a Minolta colorimeter (CRC200, Minolta Camera Co., Tokyo, Japan), and the CIELab coordinates. Three readers were taken for each fruit at three equidistant points along the equatorial perimeter and colour was expressed as $\mathrm{a}^{*} / \mathrm{b}^{*}$ ratio, which is a good index for sweet cherry colour [1]. The results are the mean \pm SE. To measure fruit firmness, a TX-XT2i Texture Analyser (Stable Mycrosystems, Godalming, UK) equipped with a flat probe was used. The machine measured fruit diameter and applied a force to achieve a 3\% fruit diameter deformation. Fruit firmness was expressed as the relation between the applied force and the travelled distance $\left(\mathrm{N} \mathrm{mm}^{-1}\right)$ and results are the mean $\pm \mathrm{SE}$. After that, the flesh of the 20 fruit of each replicate was cut in small pieces to obtain a homogeneous sample. About $50 \mathrm{~g}$ were squeezed through two layers of cotton cloth and the juice was used to measure, in duplicate, the total soluble solids (TSS) and titratable acidity (TA). Other $50 \mathrm{~g}$ of sample was frozen under liquid $\mathrm{N}_{2}$, ground and stored at $-20^{\circ} \mathrm{C}$ to measure total phenolics and anthocyanins. To measure TA, $1 \mathrm{~mL}$ of juice was diluted in $25 \mathrm{~mL}$ of distilled $\mathrm{H}_{2} \mathrm{O}$ and titrated with $0.1 \mathrm{~N}$ $\mathrm{NaOH}$ up to $\mathrm{pH} 8.1$ by using an automatic titration system (785 DMP Titrino, Metrohm, Herisau, Switzerland). The results (mean $\pm \mathrm{SE}$ ) were expressed as g malic acid equivalent $100 \mathrm{~g}^{-1}$ in fresh weight basis. TSS were measured in the juice of each sample by using a digital refractometer (Atago PR-101, Atago Co. Ltd., Tokyo, Japan) at $20{ }^{\circ} \mathrm{C}$ and results (mean $\pm \mathrm{SE}$ ) were expressed as $100 \mathrm{~g}^{-1}$ on a fresh weight basis.

\subsection{Total Phenolic and Anthocyanin Quantification}

To extract the total phenolis compounds, $5 \mathrm{~g}$ of pulp were homogenised with $15 \mathrm{~mL}$ of water:methanol $(2: 8, v / v)$ containing $2 \mathrm{mM} \mathrm{NaF}$ for $30 \mathrm{~s}$, by using an Ultraturrax (T18 basic, IKA, Berlin, Germany). The extracts were centrifuged at $10,000 \times g$ for $10 \mathrm{~min}$ at $4{ }^{\circ} \mathrm{C}$ and the supernatant was used to quantify total phenolics in duplicate according to Díaz-Mula et al. [1]. Briefly, $50 \mu \mathrm{L}$ of appropriately diluted extracts were mixed with $2.5 \mathrm{~mL}$ of water-diluted Folin-Ciocalteau reagent and incubated for $2 \mathrm{~min}$ at room temperature. Then, $2 \mathrm{~mL}$ of sodium carbonate $\left(75 \mathrm{~g} \mathrm{~L}^{-1}\right)$ was added and shaken vigorously. Thereafter, the mixture was incubated in a water bath at $50{ }^{\circ} \mathrm{C}$ for $15 \mathrm{~min}$, and finally, the absorbance was measured at $760 \mathrm{~nm}$. A calibration curve was performed with gallic acid and results (mean \pm SE) were expressed as mg gallic acid equivalent $100 \mathrm{~g}^{-1}$ on a fresh weight basis. Total anthocyanins were extracted by homogenising $5 \mathrm{~g}$ of flesh with $15 \mathrm{~mL}$ of methanol/formic acid/water (25:1:24, $v / v / v)$. The extracts were centrifuged at 10,000 $\times g$ for $10 \mathrm{~min}$ at $4{ }^{\circ} \mathrm{C}$ and the supernatant was used to quantify total anthocyanins by reading absorbance at $520 \mathrm{~nm}$ according to previous report [16]. The results were expressed as mg $100 \mathrm{~g}^{-1}$ of cyaniding 3-glucoside equivalent (cyn 3-glu, molar absorption coefficient of $26,900 \mathrm{~L} \mathrm{~cm}^{-1} \mathrm{~mol}^{-1}$ and molecular weight of $449.2 \mathrm{~g} \mathrm{~mol}^{-1}$ ). Individual anthocyanins were quantified, in duplicate, in the previous extracts after filtration through $0.45 \mu \mathrm{m}$ PVDF filter (Millex HV13, Millipore, Bedford, MA, USA) by using HPLC analysis, as previously described by Martínez-Esplá et al. [3]. In brief, $20 \mu \mathrm{L}$ of the extracts were injected into a HPLC system (Agilent HPLC 1200 Infinity series, Santa Clara, CA, United States) and chromatograms were recorded at $520 \mathrm{~nm}$. Individual anthocyanins were quantified by comparison with standard calibration curves performed with cyanidin 3-rutinoside (Cyn 3-rut), pelargonidin 3-rutinoside (Pelg 3-rut) and cyanidin 3-glucoside Cyn 3-gluc) and 
results were expressed as $\mathrm{mg} 100 \mathrm{~g}^{-1}$ (mean \pm SE of measures in duplicate in each of the three replicates).

\subsection{Statistical Analysis}

A factorial design with melatonin treatments $(0,0.1,0.3$ and $0.5 \mathrm{mM})$ with three triplicates $(n=3)$ of three trees per replicate was performed for each sweet cherry cultivar and year (2019 and 2020). For all the measured parameters, year and cultivar, data are the mean $\pm \mathrm{SE}$ of three replicates $(n=3)$. An analysis of variance (ANOVA) was performed by using the SPSS software version 20 (SPSS Inc., Chicago, IL, USA) and means were compared by Tukey's test to find significant differences among treatments at $p<0.05$. In addition, a $t$-test was performed by comparison between control and melatonin-treated fruit, for each cultivar and year. Finally, linear regressions were performed between colour $\mathrm{a}^{*} / \mathrm{b}^{*}$ index and anthocyanin content and between total anthocyanin and phenolic concentration separately for each cultivar and each year.

\section{Results}

\subsection{Crop Yield and Fruit Weight}

Sweet cherry fruit were harvested when fruit reached their commercial ripening stage, according to commercial practices. Preharvest melatonin treatments at 0.3 and $0.5 \mathrm{mM}$ concentrations significantly $(p<0.05)$ increased the total yield of the 'Lapins' cultivar in 2019, while in the 2020 experiment, significant increases were found for $0.3 \mathrm{mM}$ (Figure 1). However, no significant effects of melatonin treatments on yield were observed for 'Prime Giant' or 'Sweet Heart' cultivars. In addition, important differences in total yield were observed for both years. Thus, for the 'Lapins' cultivar, the total yield of control trees was $19.02 \pm 2.31 \mathrm{~kg}$ tree ${ }^{-1}$ in 2019 and $35.33 \pm 1.92 \mathrm{~kg} \mathrm{tree}^{-1}$ in 2020 . On the contrary, for the 'Prime Giant' cultivar, the yield of control trees was 2.5-fold reduced from 2019 to 2020 (Figure 1). Moreover, a great proportion $(50.50 \pm 3.19 \%)$ of the 'Prime Giant' harvested fruit from control trees in the 2020 experiment were decayed or cracked fruit (unmarketable fruit), while this proportion was significantly $(p<0.05)$ reduced in melatonin-treated trees, in a concentration-dependent way, up to $32.66 \pm 2.53 \%$ in $0.5 \mathrm{mM}$ treated trees, leading to significant increases in commercial yield (Figure 2). The percentage of unmarketable fruit (decayed and cracked fruit) from control trees in the 2020 experiment was very low for 'Lapins' and 'Sweet Heart' cultivars (less than 5\%), although they were also significantly $(p<0.05)$ reduced by melatonin treatments and commercial yield was increased, the higher effect being observed with $0.3 \mathrm{mM}$ concentration (Figure 2). Fruit weight of 'Prime Giant' cherries from control trees was ca. 11 and $13.5 \mathrm{~g}$ in 2019 and 2020, respectively, and significantly higher $(p<0.05)$ in fruit from melatonin-treated trees (except for $0.5 \mathrm{mM}$ dose in 2019), the major increases (9-13\%) being found for 0.1 and $0.3 \mathrm{mM}$ doses in both years. For the 'Sweet Heart' cultivar, fruit weight was also increased by melatonin treatments, from 4 to $8 \%$ for 0.1 to $0.5 \mathrm{mM}$ doses, while for the 'Lapins' cultivar, the effect of melatonin treatments on increasing fruit weight was significant only for the $0.5 \mathrm{mM}$ dose in the 2020 experiment (Figure 3). 


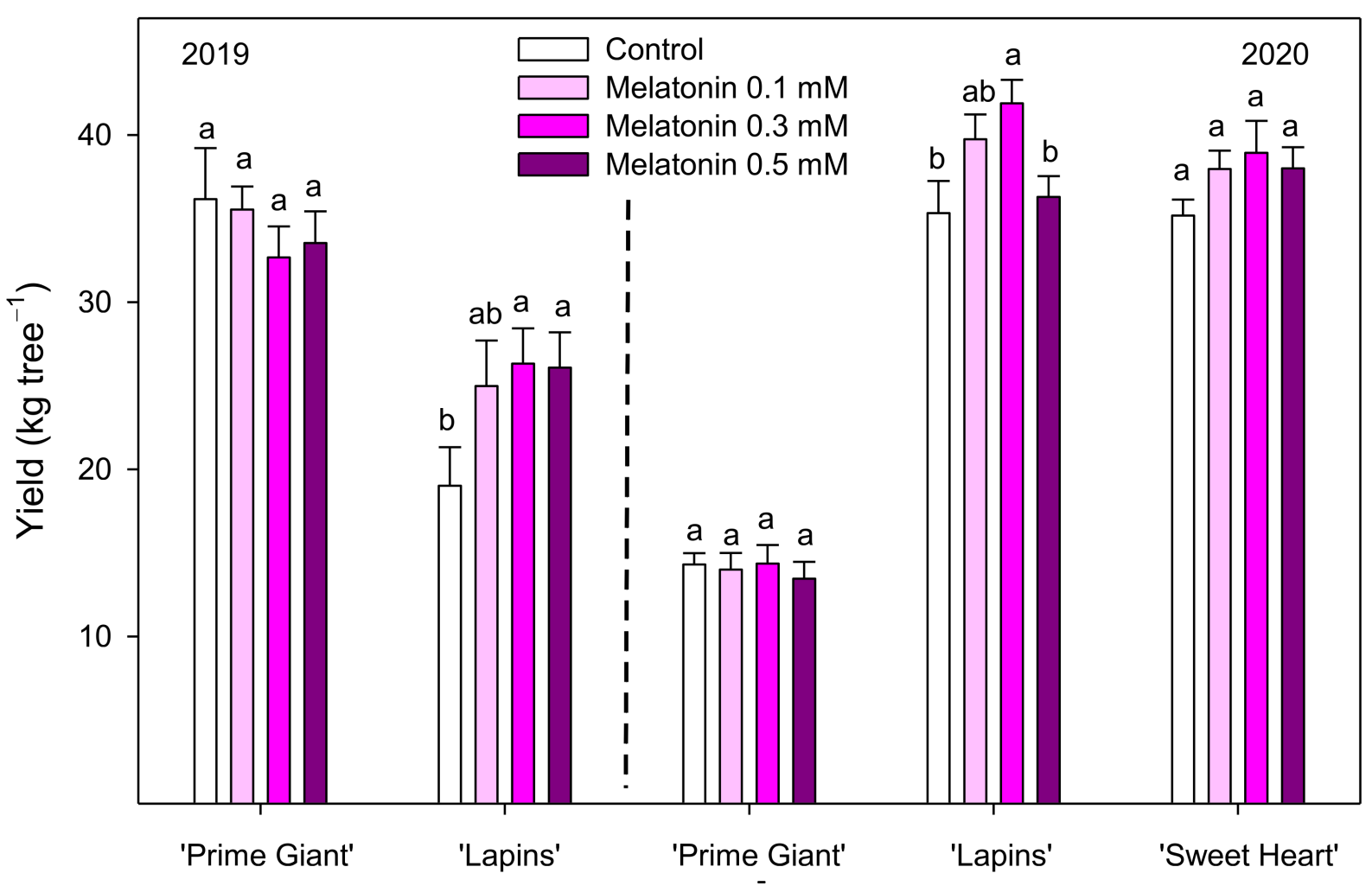

Figure 1. Yield ( $\mathrm{kg}$ tree $\left.{ }^{-1}\right)$ in control and melatonin-treated trees in the 2019 and 2020 experiments. Data are the mean \pm SE of three replicates of three trees. Different letters show significant differences $(p<0.05)$ between treatments for each cultivar and year.

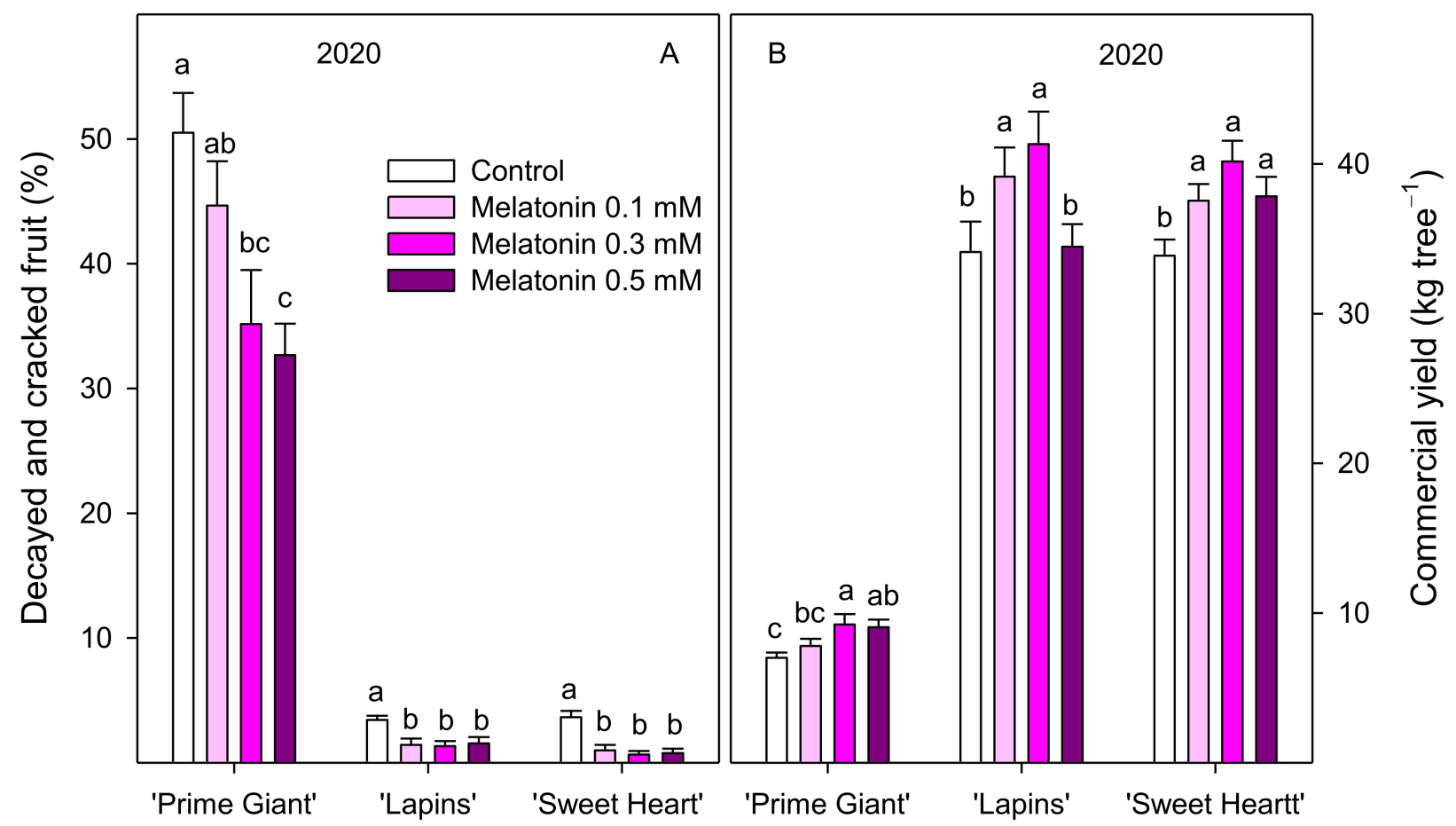

Figure 2. Decayed and cracked fruit (A) and commercial yield (B) in control and melatonin-treated trees in the 2020 experiments. Data are the mean \pm SE of three replicates of three trees. Different letters show significant differences $(p<0.05)$ between treatments for each cultivar and year. 


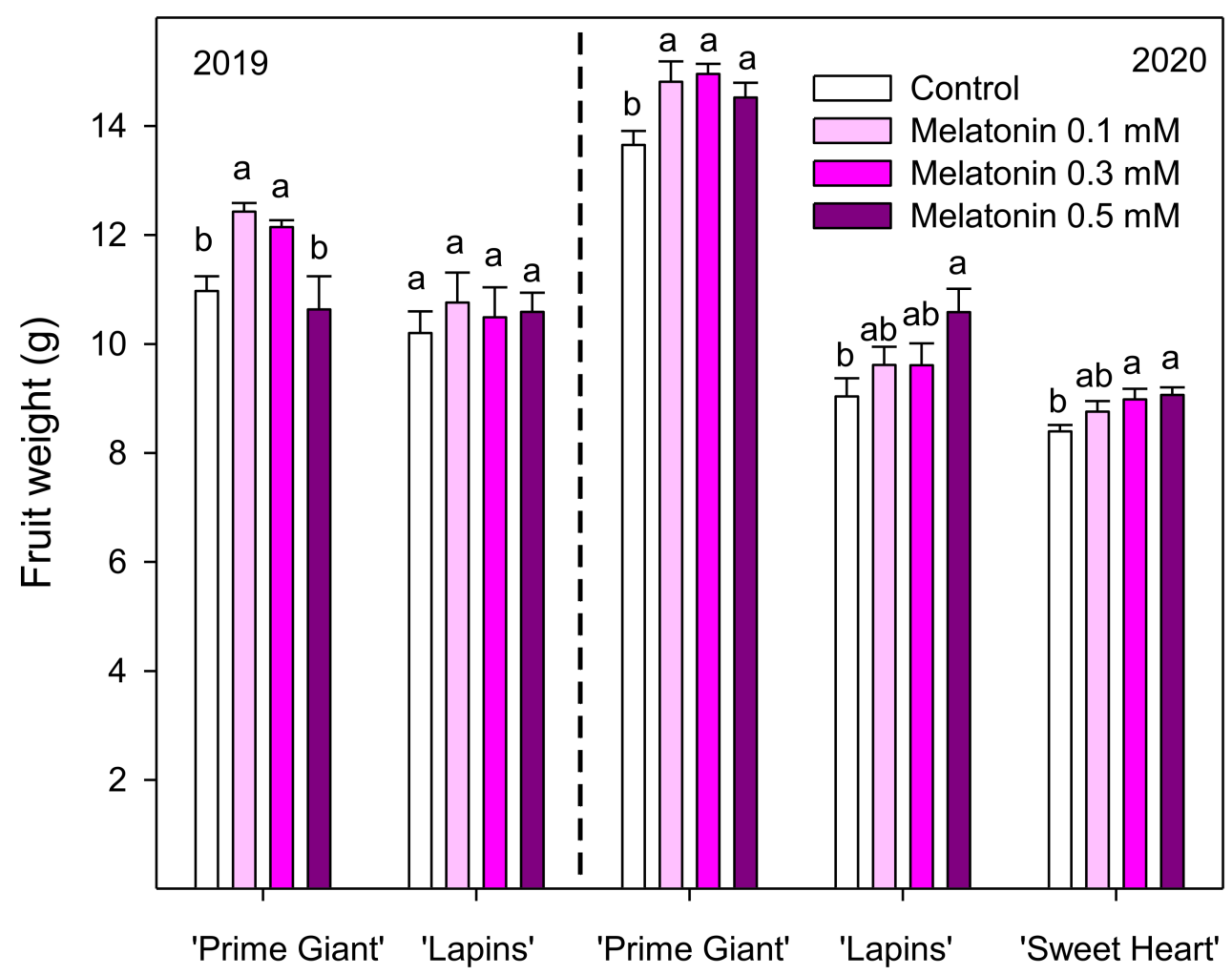

Figure 3. Effects of sweet cherry trees' melatonin treatments on fruit weight (g) in the 2019 and 2020 experiments. Data are the mean $\pm \mathrm{SE}$ of 100 fruit taken at random from commercial fruit of control or treated trees. Different letters show significant differences $(p<0.05)$ between treatments for each cultivar and year.

\subsection{Fruit Quality Parameters}

The surface skin colour, expressed as the $\mathrm{a}^{*} / \mathrm{b}^{*}$ index, was 3.1-3.2 in 'Prime Giant' and 'Sweet Heart' cultivars and ca. 4.3 in 'Lapins' for control fruit, showing a deeper red colour in the last cultivar (Table 2). However, sweet cherries from melatonin-treated trees showed significantly $(p<0.05)$ higher $\mathrm{a}^{*} / \mathrm{b}^{*}$ colour index for all assayed cultivars and, in general, the highest values were found for $0.5 \mathrm{mM}$ dose. Significantly $(p<0.05)$ higher values of fruit firmness were also observed in fruit from melatonin-treated trees with respect to those from control trees. However, for this quality parameter, no significant differences were observed among the applied melatonin doses, except for 'Prime Giant' in 2019, in which the highest firmness values were found in fruit from 0.3 and $0.5 \mathrm{mM}$ melatonin-treated trees (Table 2). With respect to TSS content, values of 20.4 and $22.3 \mathrm{~g} 100 \mathrm{~g}^{-1}$ were found in control fruit of

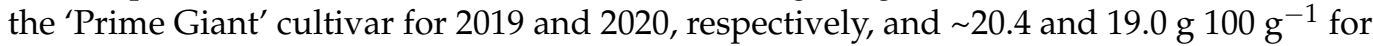
'Lapins', showing differences on this quality parameter between different growing years and cultivars. Nevertheless, a similar effect of preharvest melatonin treatments on TSS was observed for all cultivar and years, since TSS values were significantly $(p<0.05)$ enhanced by these treatments (Table 2). In general, the highest increases were found with 0.3 and $0.5 \mathrm{mM}$ doses, ranging from 15\% in 'Prime Giant' in the 2019 experiment to 5\% in 'Sweet Heart' in the 2020 experiment. Finally, TA values were also significantly $(p<0.05)$ increased by preharvest melatonin treatments, ranging from 10 to $20 \%$, depending on cultivar and year, without significant differences attributed to melatonin concentration (Table 2). 
Table 2. Effects of preharvest melatonin treatments at $0.1,0.3$ and $0.5 \mathrm{mM}$ concentration on fruit colour, firmness, total soluble solids and titratable acidity.

\begin{tabular}{|c|c|c|c|c|c|}
\hline \multirow[b]{2}{*}{ Cultivar } & \multirow[b]{2}{*}{ Year } & \multicolumn{4}{|c|}{ Melatonin Concentration } \\
\hline & & Control & $0.1 \mathrm{mM}$ & $0.3 \mathrm{mM}$ & $0.5 \mathrm{mM}$ \\
\hline & & \multicolumn{4}{|c|}{ Fruit Colour $\left(a^{*} / b^{*}\right)$} \\
\hline 'Prime Giant' & 2019 & $3.20 \pm 0.07 c$ & $3.47 \pm 0.07 \mathrm{~b}$ & $3.47 \pm 0.06 b$ & $3.92 \pm 0.06 a$ \\
\hline ‘Prime Giant' & 2020 & $3.12 \pm 0.09 c$ & $3.37 \pm 0.11 b$ & $3.50 \pm 0.07 b$ & $3.72 \pm 0.11 \mathrm{a}$ \\
\hline 'Lapins' & 2019 & $4.25 \pm 0.07 c$ & $4.55 \pm 0.07 \mathrm{~b}$ & $4.50 \pm 0.07 \mathrm{~b}$ & $4.76 \pm 0.07 a$ \\
\hline ‘Lapins' & 2020 & $4.33 \pm 0.11 b$ & $4.77 \pm 0.14 \mathrm{a}$ & $4.73 \pm 0.09 a$ & $4.68 \pm 0.09 a$ \\
\hline \multirow[t]{2}{*}{ ‘Sweet Heart' } & 2020 & $3.13 \pm 0.17 \mathrm{c}$ & $3.43 \pm 0.11 b$ & $3.59 \pm 0.03 b$ & $3.79 \pm 0.07 a$ \\
\hline & & \multicolumn{4}{|c|}{ Fruit firmness $\left(\mathrm{N} \mathrm{mm}^{-1}\right)$} \\
\hline ‘Prime Giant' & 2019 & $1.59 \pm 0.04 c$ & $1.83 \pm 0.04 b$ & $2.02 \pm 0.04 a$ & $1.91 \pm 0.03 \mathrm{a}$ \\
\hline 'Prime Giant' & 2020 & $1.49 \pm 0.08 b$ & $1.84 \pm 0.09 a$ & $1.99 \pm 0.06 a$ & $1.78 \pm 0.10 \mathrm{a}$ \\
\hline 'Lapins' & 2019 & $1.56 \pm 0.05 b$ & $1.73 \pm 0.04 \mathrm{a}$ & $1.80 \pm 0.04 a$ & $1.77 \pm 0.04 \mathrm{a}$ \\
\hline 'Lapins' & 2020 & $1.60 \pm 0.05 a$ & $1.83 \pm 0.06 \mathrm{a}$ & $1.81 \pm 0.04 \mathrm{a}$ & $1.80 \pm 0.04 \mathrm{a}$ \\
\hline \multirow[t]{2}{*}{ 'Sweet Heart' } & 2020 & $1.54 \pm 0.07 \mathrm{~b}$ & $1.87 \pm 0.06 a$ & $2.05 \pm 0.09 a$ & $1.85 \pm 0.05 a$ \\
\hline & & \multicolumn{4}{|c|}{ Total soluble solids (g $100 \mathrm{~g}^{-1}$ ) } \\
\hline ‘Prime Giant' & 2019 & $20.43 \pm 0.24 c$ & $22.45 \pm 0.12 b$ & $23.00 \pm 0.12 \mathrm{ab}$ & $23.47 \pm 0.41 a$ \\
\hline ‘Prime Giant' & 2020 & $22.28 \pm 0.22 b$ & $23.93 \pm 0.45 a$ & $23.77 \pm 0.23 a$ & $24.27 \pm 0.17 a$ \\
\hline 'Lapins' & 2019 & $20.36 \pm 0.14 b$ & $21.40 \pm 0.26 a$ & $22.10 \pm 0.47 \mathrm{a}$ & $22.17 \pm 0.16 a$ \\
\hline ‘Lapins' & 2020 & $18.98 \pm 0.12 c$ & $20.07 \pm 0.06 b$ & $20.52 \pm 0.22 \mathrm{ab}$ & $21.05 \pm 0.08 \mathrm{a}$ \\
\hline \multirow[t]{2}{*}{ 'Sweet Heart' } & 2020 & $19.70 \pm 0.21 b$ & $20.92 \pm 0.07 a$ & $20.75 \pm 0.16 a$ & $20.72 \pm 0.38 \mathrm{a}$ \\
\hline & & \multicolumn{4}{|c|}{ Titratable acidity $\left({\left.\mathrm{g} 100 \mathrm{~g}^{-1}\right)}^{-1}\right.$} \\
\hline ‘Prime Giant' & 2019 & $1.10 \pm 0.01 b$ & $1.31 \pm 0.02 \mathrm{a}$ & $1.24 \pm 0.03 a$ & $1.22 \pm 0.01 \mathrm{a}$ \\
\hline ‘Prime Giant' & 2020 & $1.25 \pm 0.01 b$ & $1.40 \pm 0.02 \mathrm{a}$ & $1.39 \pm 0.02 \mathrm{a}$ & $1.36 \pm 0.03 a$ \\
\hline 'Lapins' & 2019 & $0.95 \pm 0.01 b$ & $1.15 \pm 0.03 \mathrm{a}$ & $1.12 \pm 0.01 \mathrm{a}$ & $1.09 \pm 0.02 \mathrm{a}$ \\
\hline 'Lapins' & 2020 & $1.08 \pm 0.02 b$ & $1.21 \pm 0.01 \mathrm{a}$ & $1.18 \pm 0.01 \mathrm{a}$ & $1.17 \pm 0.01 \mathrm{a}$ \\
\hline 'Sweet Heart' & 2020 & $1.22 \pm 0.01 b$ & $1.37 \pm 0.04 \mathrm{a}$ & $1.35 \pm 0.02 \mathrm{a}$ & $1.36 \pm 0.03 a$ \\
\hline
\end{tabular}

Data are the mean \pm SE of fruits harvested from three replicates of three trees for the 2019 and 2020 experiments. For each cultivar and year, different lowercase letters show significant differences $(p<0.05)$ between treatments.

\subsection{Total Phenolics and Total and Individual Anthocyanins}

Total phenolic concentration was different depending on cultivar, year and melatonin dose applied. In control fruit of the 'Prime Giant' cultivar, the total phenolic content at

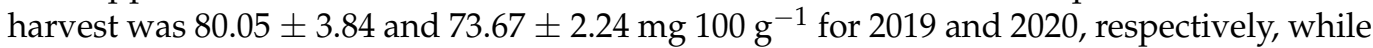
for 'Lapins', cultivar important differences were found for both years, $64.45 \pm 1.22$ and $107.48 \pm 3.96 \mathrm{mg} 100 \mathrm{~g}^{-1}$, respectively. However, in general, for all cultivars and years, preharvest treatments with melatonin led to significant increases $(p<0.05)$ in phenolic concentration, the major effects being observed for 0.3 and $0.5 \mathrm{mM}$ doses, with increases up to $45 \%$ in the 'Lapins' cultivar in the 2019 experiment compared to the controls (Figure 4). With respect to the anthocyanin concentration, it was significantly increased $(p<0.05)$ by all applied melatonin doses in both experimental years and cultivars. The highest effects were found in the 2019 experiment for the $0.5 \mathrm{mM}$ dose, which led to 82 and $57 \%$ increases in 'Prime Giant' and 'Lapins' cultivars, respectively. In the 2020 experiment, all melatonin treatments increased anthocyanin concentration, these increases ranging from 14 to $25 \%$, although no significant differences $(p<0.05)$ among melatonin concentrations were observed for any of the three assayed cultivars (Figure 5). 


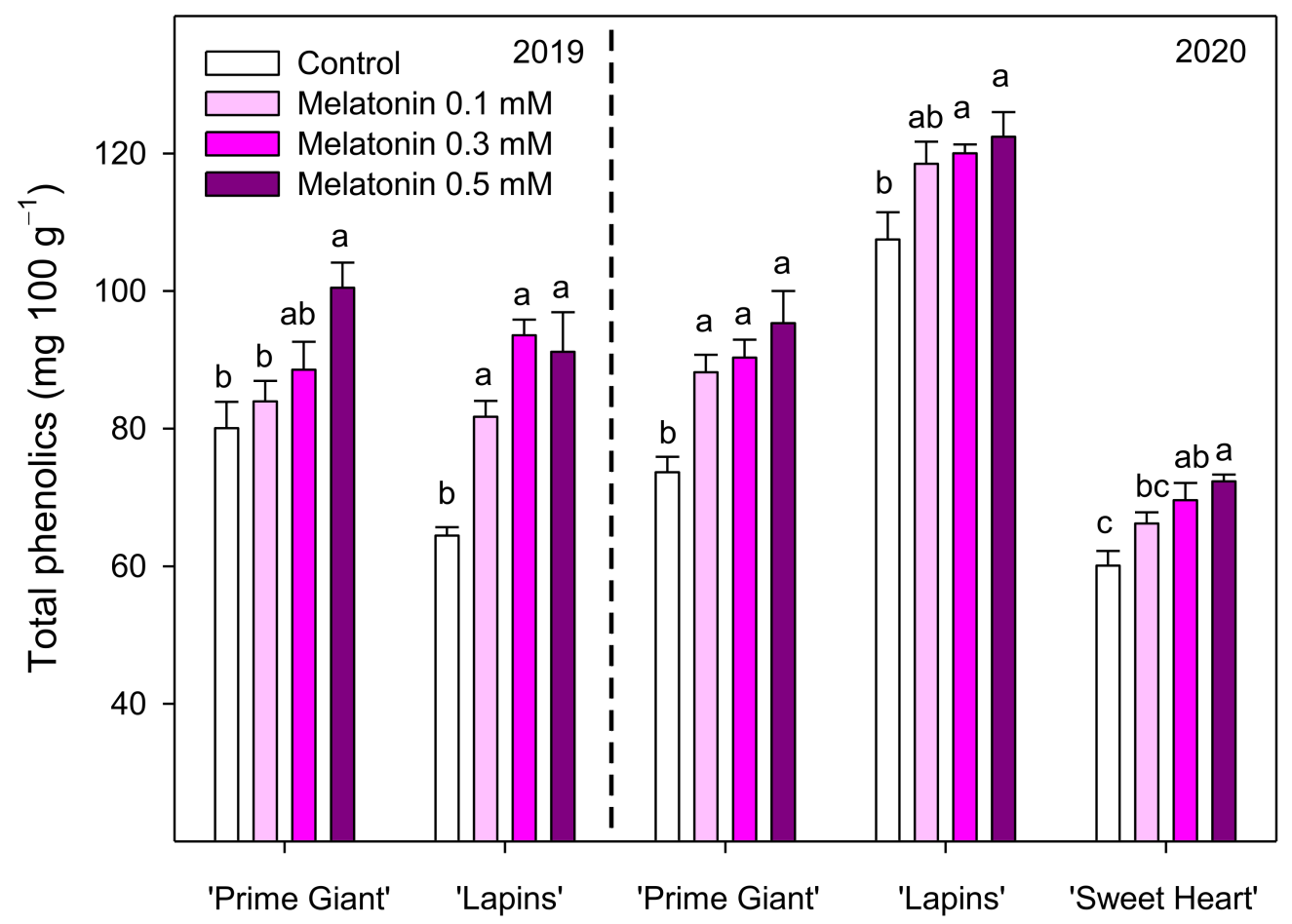

Figure 4. Total phenolic concentration in sweet cherries from control and melatonin-treated trees in the 2019 and 2020 experiments. Data are the mean \pm SE of determinations made in duplicate in three replicates. Different letters show the significant differences $(p<0.05)$ between treatments for each cultivar and year.

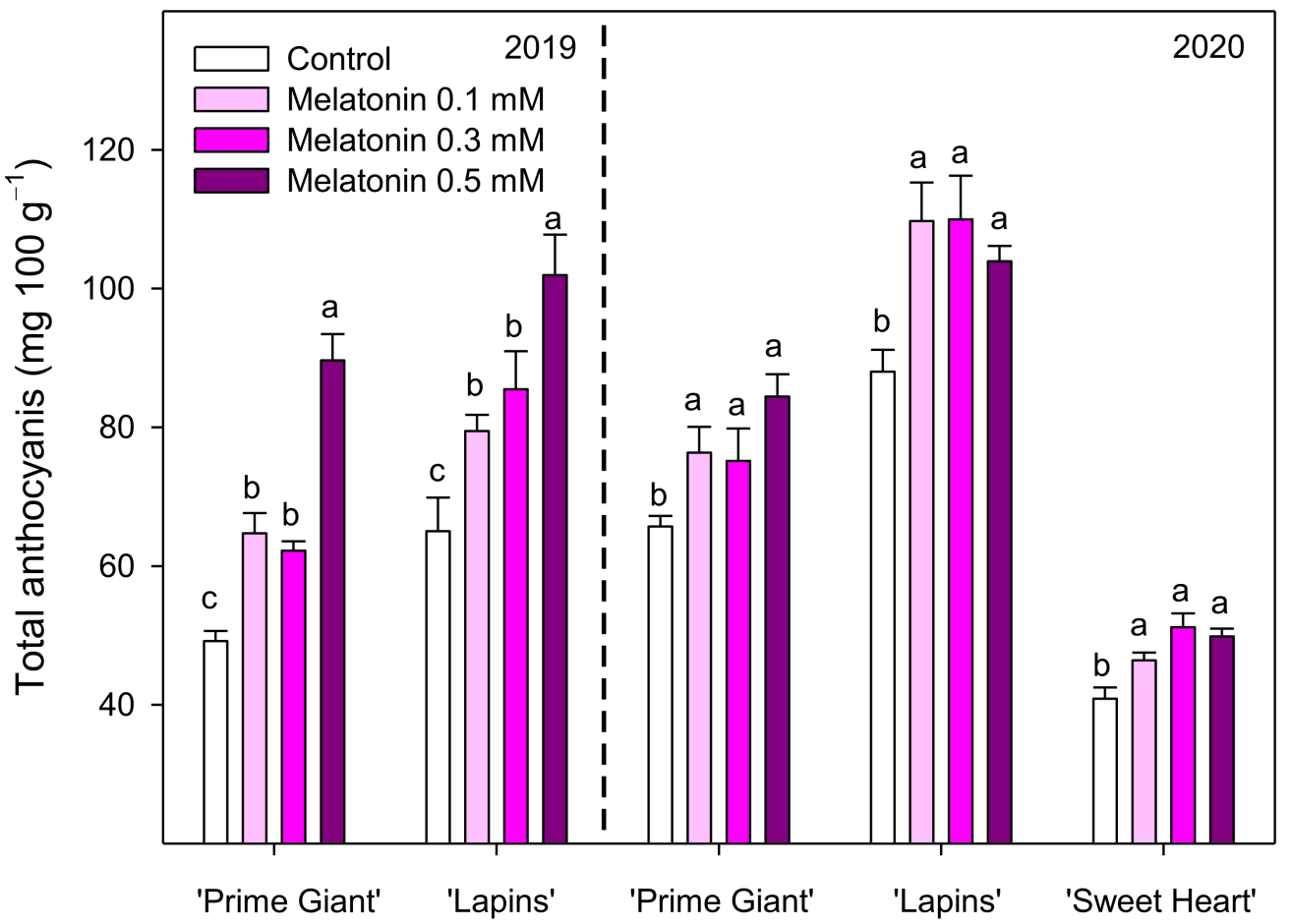

Figure 5. Total anthocyanin concentration in sweet cherries from control and melatonin-treated trees in the 2019 and 2020 experiments. Data are the mean \pm SE of determinations made in duplicate in three replicates. Different letters show significant differences $(p<0.05)$ between treatments for each cultivar and year. 
The concentration of individual anthocyanins were measured in the 2020 experiment and the result showed that cyaniding 3-O-rutinoside (Cyn 3-rut) was the major anthocyanin in all sweet cherry cultivars, with concentrations of $76.17 \pm 1.30,88.65 \pm 2.27$ and $52.11 \pm 0.62 \mathrm{mg} 100 \mathrm{~g}^{-1}$ in control fruit of 'Prime Giant', 'Lapins' and 'Sweet Heart' cultivars, respectively (Figure 6). Pelargonidin 3-O-rutinoside (Pelg 3-rut) was found at a much lower

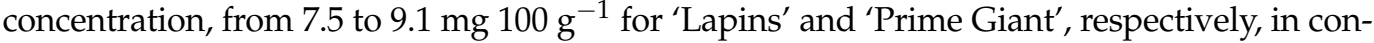
trol fruit. Cyaniding 3-O-glucoside (Cyn 3-gluc) was only found in control fruit of the 'Sweet

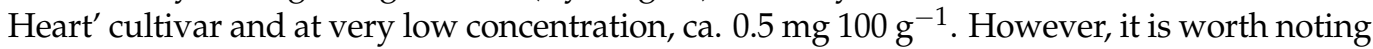
that concentrations of all individual anthocyanins were significantly $(p<0.05)$ enhanced as a consequence of melatonin pre-harvest treatments. These increments ranged from 20 to 40\% for Cyn 3-rut and from 10 to 50\% for Pelg 3-rut depending on the cultivar, although no significant differences were observed among the applied melatonin doses (Figure 6).

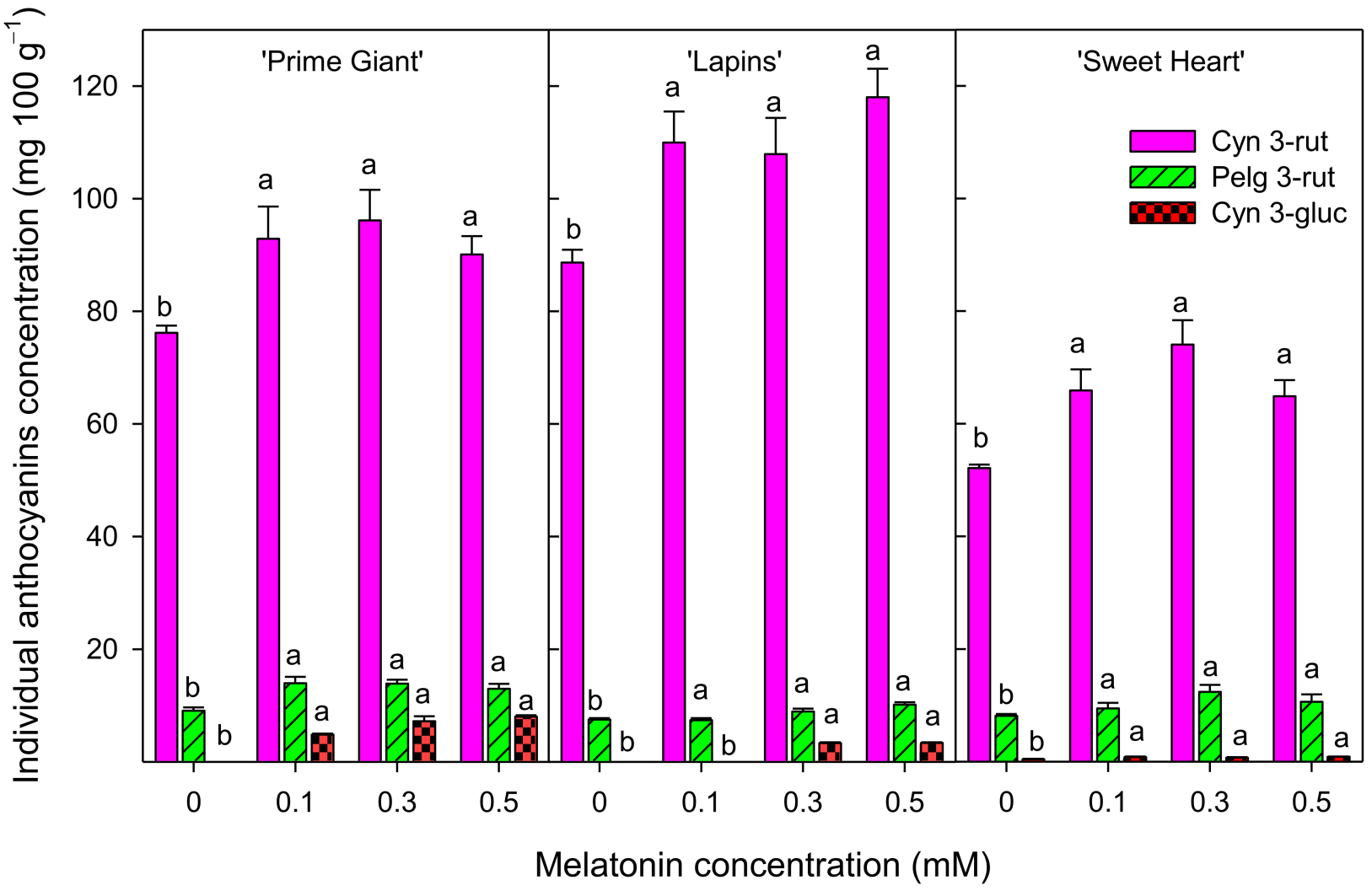

Figure 6. Individual anthocyanins concentration (cyaniding 3-rutinoside, cyn 3-rut, pelargonidin 3-rutinoside, pelg 3-rut, and cyanidin 3-glucoside, cyn 3-gluc) in sweet cherries from control and melatonin-treated trees in the 2020 experiment. Data are the mean \pm SE of determinations made in duplicate in three replicates. Different letters show significant differences $(p<0.05)$ between treatments for each cultivar.

\section{Discussion}

Melatonin treatments of cherry trees increased crop yield in the 'Lapins' cultivar in both experimental years, especially with $0.3 \mathrm{mM}$ dose, but no significant effects were observed for 'Prime Giant' or 'Sweet Heart' cultivars (Figure 1). No previously published papers are available in the literature regarding the effect of melatonin treatment of sweet cherry trees on crop yield for comparative purposes, and only a few reports are available in other fruit species. Thus, increases in crop yield as a consequence of melatonin tree treatment during fruit development have been reported in 'Colorado', 'Mikado' and 'Canino' apricots [14,15], as well as in tomato plants when seeds were soaked with melatonin or melatonin was applied in the irrigation system [13]. These effects were attributed to an increase in plant photosynthetic rate and leaf chlorophyll content. The yield of pomegranate tree was also 
increased by $0.1 \mathrm{mM}$ melatonin preharvest treatment due to increases in fruit size and number of fruit harvested by tree [22]. Similarly, a 14\% of crop yield was obtained in wellirrigated tomato plants when melatonin was applied at 30 and 50 days after transplanting, while this increase was 37\% under water deficit stress [23]. However, in another previous paper, increases in tomato crop yield in melatonin-treated plants were only found when plants were exposed to rain acid stress but not in tomato plants under optimal growth conditions [24]. Then, the effect of melatonin treatment during fruit development on plant on increasing crop yield is clear when plants are under abiotic or biotic stresses. Nevertheless, under optimal conditions this effect depends on the plant species or cultivars, the concentration applied or the plant development stage and deserves further research [25].

On the other hand, the total yield was quite different in both experimental years. Thus, for the 'Lapins' cultivar, the yield of control trees was ca. 19 and $35 \mathrm{~kg}^{\text {tree }}{ }^{-1}$ in 2019 and 2020, respectively, which could be attributed to the normal variability occurring in cherry tree between the years. In this sense, a three-fold higher yield was observed in 'Skeena' cherry trees grown in Portugal in 2016 with respect to 2015, which was attributed to a higher crop load rather than larger fruit size [26]. However, for the 'Prime Giant' cultivar, the yield of 2020 experiment was 2.5-fold reduced with respect to 2019, either in control as in treated trees (Figure 1). This reduction was due to a heavy rainfall $\left(15 \mathrm{~L} \mathrm{~m}^{2}\right)$ that occurred on May 16, causing dropping of many fruits that were at the initial colour change stage. On the contrary, 'Lapins' and 'Sweet Heart' cultivars were at the pit hardening stage when the heavy rainfall occurred and were not as highly affected as the 'Prime Giant' cultivar, reaching high yield values, which for 'Lapins' were even higher than in the 2019 experiment. In addition, in 'Prime Giant', ca. 50\% of the harvested fruit from control trees in 2020 were unmarketable fruit, due to the appearance of cracking and/or fungal decay as a consequence of the heavy rain that occurred. However, the percentage of unmarketable fruit was reduced in melatonin-treated trees, leading to increases in commercial yield, especially with a $0.3 \mathrm{mM}$ dose (Figure 2). For 'Lapins' and 'Sweet Heart' cultivars, in spite of being much less affected by these high rains and rendering a much lower percentage of unmarketable fruit in 2020, these percentages were also reduced in melatonin-treated trees.

Sweet cherry size is a quality parameter highly valued by consumers and large-sized fruit reached higher prices on the market than small ones. The results of the present experiments showed, in general, an effect of 0.3 and $0.5 \mathrm{mM}$ melatonin treatments on increasing fruit weight, although in the 'Lapins' cultivar, this effect was significant only for $0.5 \mathrm{mM}$ dose in 2020 (Figure 3). Increases in fruit size have been recently reported in pomegranate fruit from melatonin-treated trees [22] as well as on grape berries [27], which were attributed to an increase of the fruit sink strength, leading the fruit to uptake more sugars and reach larger-size at harvest. Fruit colour, firmness and TSS and TA contents are also quality parameters highly valued by consumers in sweet cherry fruit and it is worth noting that all of them were found at higher levels in fruit from melatonin-treated trees than in controls (Table 2). It has been reported in a wide range of sweet cherry cultivars that fruit firmness decreased during the on-tree ripening process, while increases occurred in colour, TSS and TA contents $[1,28,29]$. Thus, as melatonin treatment led to fruit with higher firmness at harvest, it could be inferred a delay of fruit ripening as a consequence of melatonin treatment. On the contrary, colour, TA and TSS were enhanced as a consequence of melatonin treatments, which would show an accelerate ripening. In fact, ripening in sweet cherry, as well as in other fruit species, is a complex and coordinated process and each single parameter evolves at a particular pace [30]. In the 'Ferrovia' cultivar, foliar spray with $0.5 \mathrm{mM}$ melatonin 2 and 1 weeks prior to harvest did not affect the ripening process, leading to fruit with similar TSS, TA and colour values than controls [21]. Accordingly, no significant effects of 0.1 or $0.01 \mathrm{mM}$ melatonin treatment (applied 19 days before harvesting) on fruit firmness, TA or TSS were reported for the 'Prime Giant' cultivar by Tijero et al. [20], although anthocyanin content was significantly decreased. These authors proposed that sweet cherry ripening is modulated by a delicate hormonal balance. Thus, melatonin, in combination with jasmonic and salicylic acids, would have inhibitory roles in fruit ripening, 
since these three plant hormones decreased as ripening started, while abscisic acid would have a ripening stimulatory effect since it increased with ripening. On the contrary, threefold application of 0.05 and $0.1 \mathrm{mM}$ melatonin (at week intervals, starting just before the fruit turned red) on 'Hongdeng' sweet cherry trees led to higher contents on TSS and total anthocyanins, although TA content was decreased [31]. These findings suggest that the effects on melatonin preharvest treatments on sweet cherry ripening and quality traits are notably influenced by the applied concentration, developmental stage and cultivar, among other possible factors. However, when melatonin was applied as postharvest dipping general effects on delaying postharvest fruit ripening, maintaining fruit quality traits and extending shelf-life have been reported in several fruit species, such as banana, peach, pear, kiwi, strawberry and pomegranate, as recently revised by Ze et al. [32], although the applied dose and time dipping was different for each fruit species. These effects were attributed to a reduced accumulation of reactive oxygen species (ROS) due to increases in the enzymatic activities and gene expressions of antioxidant enzymes. Even in sweet cherry, postharvest melatonin treatments, especially with $0.1 \mathrm{mM}$ dose, led to a delay of the postharvest ripening process of 'Sunbust' [18] and 'Siah Mashhad' [17] cultivars, through increasing the activity of antioxidant enzymes and concentration of antioxidant compounds, such as ascorbic acid, reduced glutathione and phenolics.

Sweet cherries are fruit with high content of phenolic compounds, mainly anthocyanins, which are primarily responsible for the beneficial health effects attributed to cherry consumption [6,33-35]. In fact, phenolic compounds and especially anthocyanins have strong antioxidant activity and preventive effects on a wide range of age-related and chronic diseases, such as neurodegenerative, cardiovascular and oncologic diseases, hypertension, obesity and diabetes, among others [36-38]. The results of the present research show enhanced levels of phenolic and total and individual anthocyanin concentrations in fruit from melatonin-treated trees in the three sweet cherry cultivars tested. In addition, high correlation was found between $\mathrm{a}^{*} / \mathrm{b}^{*}$ colour index and total anthocyanin concentration $\left(y=0.02 x+2.24 ; r^{2}=0.672\right)$, as well as between total phenolic and total anthocyanin concentrations $\left(y=0.76 x+31 ; r^{2}=0.801\right)$, taking into account data from all cultivar and years. Thus, fruit surface colour, measured by the $a^{*} / b^{*}$ index, is a good indicator of anthocyanin concentration, the pigments responsible for sweet cherry colour. Moreover, these pigments are the major phenolic compounds in these sweet cherry cultivars contributing to their antioxidant potential and health beneficial effects [33,35,39]. The predominant anthocyanin in the three sweet cherry cultivars was Cyn 3-rut followed by Pelg 3-rut and Cyn 3-gluc, in agreement with previous reports on other cherry cultivars [3,40-43]. Accordingly, Cyn 3-rut was the major anthocyanin in the 'Ferrovia' cultivar, although cyanidin 3-O-galactoside and Cyn 3-gluc were the minor ones [21]. Postharvest melatonin treatments have shown a general trend on increasing phenolic content, including anthocyanins, and antioxidant activity in a wide range of fruit species, such as 'Santa Rosa' plum [44], strawberry [45], nectarine [46], tomato [17], litchi [47] and pomegranate [48]. Accordingly, preharvest treatment of pomegranate trees led to enhanced concentrations of total phenolics and total and individual anthocyanins as well as of total antioxidant activity in arils at harvest, showing that melatonin treatment stimulated the anthocyanin biosynthesis pathway [16].

Specifically, in sweet cherry, $0.1 \mathrm{mM}$ melatonin dipping treatment increased anthocyanin concentration in 'Santina' and 'Royal Rainier' cultivar during storage due to an induced overexpression of two key genes coding for dihydroflavonol 4-reductase (DFR) and anthocyanidin 3-O-glucosyltransferase (UFGT), two enzymes involved in the last steps of anthocyanin biosynthesis partway [19]. Similarly, $0.1 \mathrm{mM}$ melatonin dipping treatment led to enhanced total phenolics, flavonoids and anthocyanins during storage in 'Siah Mashhad' cultivar, these effects being accompanied by an increased radical scavenging potential and attributed to higher phenylalanine ammonia lyase (PAL) and chalcone synthase (CHS) activities, along with decreased PPO activity [17]. However, the effect of melatonin preharvest treatment on phenolic and anthocyanin contents of sweet cherry are not as clear as those of the postharvest ones previously mentioned. Thus, Tijero et al. [20] reported 
two-fold increases in anthocyanin concentration at harvest in 'Prime Giant' after preharvest $0.1 \mathrm{mM}$ melatonin treatment at stage II, while two-fold decreases occurred with $0.01 \mathrm{mM}$ dose. In 'Hongdeng' cultivar; moreover, an increase in the total phenolic content at harvest was found after preharvest treatment with $0.05,0.01$ and $0.1 \mathrm{mM}$ melatonin (applied three times at weekly intervals from initial colour changes), while for the anthocyanin content, increases were found for 0.05 and $0.1 \mathrm{mM}$-no effect was observed for $1 \mathrm{mM}$ [31]. Finally, in the 'Ferrovia' cultivar, $0.5 \mathrm{mM}$ melatonin foliar spray treatment, 2 and 1 weeks before harvest did not affect individual phenolic or anthocyanin contents at harvest, although the expression of PAL codifying gene was significantly increased [21]. Taking into account these previous results and those obtained in the present experiments, it is clear that to obtain an increase in the phenolic and anthocyanin concentration by melatonin treatments, 0.3 and $0.5 \mathrm{mM}$ doses would be effective, provided the treatments were applied at key points of fruit development on the tree, namely pit hardening, initial colour changes and three days before harvest, as was performed in the present experiments.

\section{Conclusions}

The results show that melatonin treatment of sweet cherry trees at key points of fruit development had little effect on crop yield, except for the 'Lapins' cultivar, although the decayed and cracked fruit percentage was decreased under adverse weather conditions and commercial crop yield was increased, especially for the $0.3 \mathrm{mM}$ dose. Quality parameters at harvest, such as fruit weight, colour, firmness, TSS and TA, were enhanced by melatonin treatments in all sweet cherry cultivars and 2019 and 2020. Moreover, antioxidant compounds, such as total phenolics and total and individual anthocyanins, were also found at higher levels in fruit from melatonin-treated trees with respect to controls. Thus, considering all these effects, $0.3 \mathrm{mM}$ melatonin treatments at three key points of fruit developmental stages could be a useful tool to improve quality traits of sweet cherries and specially their content on bioactive compounds with antioxidant properties and health beneficial effects, with additional effects increasing crop yield under unfavourable climatic conditions during fruit ripening.

Author Contributions: A.C.-A., M.S., D.V. and S.C. conceived and designed the work in association with other authors. A.C.-A., J.M.V. and J.M.L.-M. performed the field treatments. A.C.-A. and J.M.L.-M. performed most of the analytical determination in collaboration with J.M.V. Finally, M.S. and D.V. analysed the data and wrote the manuscript. Funding acquisition, D.V. and M.S. All authors have read and agreed to the published version of the manuscript.

Funding: This work is included in the Project RTI2018-099664-B-I00 founded by the Spanish Ministry of Science, Innovation and Universities and the European Commission with FEDER funds.

Acknowledgments: The authors thank Spanish Ministry of Science, Innovation and Universities and Miguel Hernández University for PhD-scholarships of A.C.-A. and J.M.L.-M, respectively and to FincaToli Frutas S.L. for providing field experiments.

Conflicts of Interest: The authors declare no conflict of interest. The funders had no role in the design of the study, collection, analyses or interpretation of data, in the writing of the manuscript or in the decision to publish the results.

\section{References}

1. Díaz-Mula, H.M.; Castillo, S.; Martínez-Romero, D.; Valero, D.; Zapata, P.J.; Guillén, F.; Serrano, M. Sensory, nutritive and functional properties of sweet cherry as affected by cultivar and ripening stage. Food Sci. Technol. Int. 2009, 15, 535-543. [CrossRef]

2. Usenik, V.; Fabčič, J.; Štampar, F. Sugars, organic acids, phenolic composition and antioxidant activity of sweet cherry (Prunus avium L.). Food Chem. 2008, 107, 185-192. [CrossRef]

3. Martínez-Esplá, A.; Zapata, P.J.; Valero, D.; García-Viguera, C.; Castillo, S.; Serrano, M. Preharvest application of oxalic acid increased fruit size, bioactive compounds, and antioxidant capacity in sweet cherry cultivars (Prunus avium L.). J. Agric. Food Chem. 2014, 62, 3432-3437. [CrossRef] [PubMed]

4. McCune, L.M.; Kubota, C.; Stendell-Hollins, N.R.; Thomson, C.A. Cherries and health: A review. Crit. Rev. Food Sci. Nutr. 2011, 51, 1-12. [CrossRef] [PubMed] 
5. Blando, F.; Oomah, B.D. Sweet and sour cherries: Origin, distribution, nutritional composition and health benefits. Trends Food Sci. Technol. 2019, 86,517-529. [CrossRef]

6. Faienza, M.F.; Corbo, F.; Carocci, A.; Catalano, A.; Clodoveo, M.L.; Grano, M.; Wang, D.Q.H.; D'Amato, G.; Muraglia, M.; Franchini, C.; et al. Novel insights in health-promoting properties of sweet cherries. J. Funct. Foods 2020, 69, 103945. [CrossRef]

7. FAOSTAT. Statistical Databases On Global Food Production and Trade. Food and Agriculture Organization. 2019. Available online: https:/ / www.fao.org/statistics/en/ (accessed on 3 November 2021).

8. Dubbels, R.; Reiter, R.J.; Klenke, E.; Goebel, A.; Schnakenberg, E.; Ehleers, C.; Schiwara, H.W.; Schloot, W. Melatonin in edible plants identified by radioimmunoassay and by high performance liquid chromatography-mass spectrometry. J. Pineal Res. 1995, 18, 28-31. [CrossRef]

9. Shi, H.; Chen, K.; Wei, Y.; He, C. Fundamental issues of melatonin-mediated stress signalling in plants. Front. Plant Sci. 2016, 7, 1124. [CrossRef] [PubMed]

10. Arnao, M.B.; Hernández-Ruiz, J. Is phytomelatonin a new plant hormone? Agronomy 2020, 10, 95. [CrossRef]

11. Xu, T.; Chen, Y.; Kang, H. Melatonin is a potential target for improving post-harvest preservation of fruits and vegetables. Front. Plant Sci. 2019, 10, 1388. [CrossRef] [PubMed]

12. Arnao, M.B.; Hernández-Ruiz, J. Melatonin in flowering, fruit set and fruit ripening. Plant Reprod. 2020, 33, 77-87. [CrossRef]

13. Liu, J.; Zhang, R.; Sun, Y.; Liu, Z.; Jin, W.; Sun, Y. The beneficial effects of exogenous melatonin on tomato fruit properties. Sci. Hortic. 2016, 207, 14-20. [CrossRef]

14. Abd El-Naby, S.K.M.A.; Mohamed, A.A.A.; El-Naggar, Y.I.M. Effect of melatonin, GA3 and NAA on vegetative growth, yield and quality of 'Canino' apricot fruits. Acta Sci. Pol. Hortorum Cultus 2019, 18, 167-174. [CrossRef]

15. Medina-Santamarina, J.; Zapata, P.J.; Valverde, J.M.; Valero, D.; Serrano, M.; Guillén, F. Melatonin treatment of apricot trees leads to maintenance of fruit quality attributes during storage at chilling and non-chilling temperatures. Agronomy 2021, 11, 917. [CrossRef]

16. Lorente-Mento, J.M.; Guillén, F.; Castillo, S.; Martínez-Romero, D.; Valverde, J.M.; Valero, D.; Serrano, M. Melatonin treatment to pomegranate trees enhances fruit bioactive compounds and quality traits at harvest and during postharvest storage. Antioxidants 2021, 10, 820. [CrossRef]

17. Sharafi, Y.; Jannatizadeh, A.; Fard, J.R.; Aghdam, M.S. Melatonin treatment delays senescence and improves antioxidant potential of sweet cherry fruits during cold storage. Sci. Hortic. 2021, 288, 110304. [CrossRef]

18. Wang, F.; Zhang, X.; Yang, Q.; Zhao, Q. Exogenous melatonin delays postharvest fruit senescence and maintains the quality of sweet cherries. Food Chem. 2019, 301, 125311. [CrossRef]

19. Miranda, S.; Vilches, P.; Suazo, M.; Pavez, L.; García, K.; Méndez, M.; González, M.; Meisel, L.; Defilippi, B.G.; Del Pozo, T. Melatonin triggers metabolic and gene expression changes making possible improved quality traits of two sweet cherry cultivars during cold storage. Food Chem. 2020, 319, 126360. [CrossRef]

20. Tijero, V.; Muñoz, P.; Munné-Bosch, S. Melatonin as an inhibitor of sweet cherries ripening in orchard trees. Plant Physiol. Biochem. 2019, 140, 88-95. [CrossRef]

21. Michailidis, M.; Tanou, G.; Sarrou, E.; Karagiannis, E.; Ganopoulos, I.; Martens, S.; Molassiotis, A. Pre- and post-harvest melatonin application boosted phenolic compounds accumulation and altered respiratory characters in sweet cherry fruit. Front. Nutr. 2021, 8, 695061. [CrossRef] [PubMed]

22. Medina-Santamarina, J.; Serrano, M.; Lorente-Mento, J.M.; García-Pastor, M.E.; Zapata, P.J.; Valero, D.; Guillén, F. Melatonin treatment of pomegranate trees increases crop yield and quality parameters at harvest and during storage. Agronomy 2021, 11, 861. [CrossRef]

23. Ibrahim, M.F.M.; Abd Elbar, O.H.; Farag, R.; Hikal, M.; El-Kelish, A.; El-Yazied, A.A.; Alkahtani, J.; Abd El-Gawad, H.G. Melatonin counteracts drought induced oxidative damage and stimulates growth, productivity and fruit quality properties of tomato plants. Plants 2020, 9, 1276. [CrossRef]

24. Debnath, B.; Hussain, M.; Li, M.; Lu, X.; Sun, Y.; Qiu, D. Exogenous melatonin improves fruit quality features, health promoting antioxidant compounds and yield traits in tomato fruits under acid rain stress. Molecules 2018, 23, 1868. [CrossRef]

25. Debnath, B.; Islam, W.; Li, M.; Sun, Y.T.; Lu, X.C.; Mitra, S.; Hussain, M.; Liu, S.; Qiu, D. Melatonin mediates enhancement of stress tolerance in plants. Int. J. Mol. Sci. 2019, 20, 1040. [CrossRef]

26. Correia, S.; Queirós, F.; Ferreira, H.; Morais, M.C.; Afonso, S.; Silva, A.P.; Gonçalves, B. Foliar application of calcium and growth regulators modulate sweet cherry (Prunus avium L.) tree performance. Plants 2020, 9, 410. [CrossRef] [PubMed]

27. Meng, J.F.; Xu, T.F.; Song, C.Z.; Yu, Y.; Hu, F.; Zhang, L.; Zhang, Z.W.; Xi, Z.M. Melatonin treatment of pre-veraison grape berries to increase size and synchronicity of berries and modify wine aroma components. Food Chem. 2015, 185, 127-134. [CrossRef] [PubMed]

28. Drake, S.R.; Elfving, D.C. Indicators of maturity and storage quality of 'Lapins' sweet cherry. HortTechnology 2002, 12, 687-690. [CrossRef]

29. Serrano, M.; Guillén, F.; Martínez-Romero, D.; Castillo, S.; Valero, D. Chemical constituents and antioxidant activity of sweet cherry at different ripening stages. J. Agric. Food Chem. 2005, 53, 2741-2745. [CrossRef]

30. Valero, D.; Serrano, M. Postharvest Biology and Technology for Preserving Fruit Quality; CRC Press: Boca Raton, FL, USA, 2010. [CrossRef]

31. Xia, H.; Shen, Y.; Shen, T.; Wang, X.; Zhang, X.; Hu, P.; Liang, D.; Lin, L.; Deng, Q.; Lv, X. Melatonin accumulation in sweet cherry and its influence on fruit quality and antioxidant properties. Molecules 2020, 25, 753. [CrossRef] [PubMed] 
32. Ze, Y.; Gao, H.; Li, T.; Yang, B.; Jiang, Y. Insights into the roles of melatonin in maintaining quality and extending shelf life of postharvest fruits. Trends Food Sci. Technol. 2021, 109, 569-578. [CrossRef]

33. Correia, S.; Schouten, R.; Silva, A.P.; Gonçalves, B. Factors affecting quality and health promoting compounds during growth and postharvest life of sweet cherry (Prunus avium L.). Front. Plant Sci. 2017, 8, 2166. [CrossRef] [PubMed]

34. Gonçalves, A.C.; Bento, C.; Jesus, F.; Alves, G.; Silva, L.R. Sweet cherry phenolic compounds: Identification, characterization, and health benefits. Stud. Nat. Prod. Chem. 2018, 59, 31-78. [CrossRef]

35. Gonçalves, A.C.; Bento, C.; Silva, B.; Simões, M.; Silva, L.R. Nutrients, bioactive compounds and bioactivity: The health benefits of sweet cherries (Prunus avium L.). Curr. Nutr. Food Sci. 2019, 15, 208-227. [CrossRef]

36. Sureda, A.; Bibiloni, M.M.; Julibert, A.; Bouzas, C.; Argelich, E.; Llompart, I.; Pons, A.; Tur, J.A. Adherence to the Mediterranean diet and inflammatory markers. Nutrients 2018, 10, 62. [CrossRef] [PubMed]

37. Tarangon, E.; Moreno, J.J. Polyphenols and taste 2 receptors. Physiological, pathophysiological and pharmacological implications Biochem. Pharmacol. 2020, 78, 114086. [CrossRef]

38. Luo, J.; Si, H.; Jia, Z.; Liu, D. Dietary anti-aging polyphenols and potential mechanisms. Antioxidants 2021, 10, 283. [CrossRef]

39. Antognoni, F.; Potente, G.; Mandrioli, R.; Angeloni, C.; Freschi, M.; Malaguti, M.; Hrelia, S.; Lugli, S.; Gennari, F.; Muzzi, E.; et al. Fruit quality characterization of new sweet cherry cultivars as a good source of bioactive phenolic compounds with antioxidant and neuroprotective potential. Antioxidants 2020, 9, 677. [CrossRef] [PubMed]

40. Mozetič, B.; Simčič, M.; Trebše, P. Anthocyanins and hidroxycinnamic acids of Lambert Compact cherries (Prunus avium L.) after cold storage and 1-methylcyclorpoene treatments. Food Chem. 2006, 97, 302-309. [CrossRef]

41. Gonçalves, B.; Silva, A.P.; Moutinho-Pereia, J.; Bacelar, E.; Rosa, E.; Meyer, A.S. Effect of ripeness and postharvest storage on the evolution of color and anthocyanins in cherries (Prunus avium L.). Food Chem. 2007, 103, 976-984. [CrossRef]

42. Serrano, M.; Díaz-Mula, H.; Zapata, P.J.; Castillo, S.; Guillén, F.; Martínez-Romero, D.; Valverde, J.M.; Valero, D. Maturity stage at harvest determines the fruit quality and antioxidant potential after storage of sweet cherry cultivars. J. Agric. Food Chem. 2009, 57, 3240-3246. [CrossRef]

43. Sharma, M.; Jacob, J.K.; Subramanian, J.; Paliyath, G. Hexanal and 1-MCP treatments for enhancing the shelf life and quality of sweet cherry (Prunus avium L.). Sci. Hortic. 2010, 125, 239-247. [CrossRef]

44. Bal, E. Physicochemical changes in 'Santa Rosa' plum fruit treated with melatonin during cold storage. J. Food Meas. Charact. 2019, 13, 1713-1720. [CrossRef]

45. Liu, C.H.; Zheng, H.H.; Sheng, K.L.; Liu, W.; Zheng, L. Effects of melatonin treatment on the postharvest quality of strawberry fruit. Postharvest Biol. Technol. 2018, 139, 47-55. [CrossRef]

46. Bal, E. Effect of melatonin treatments on biochemical quality and postharvest life of nectarines. J. Food Meas. Charact. 2021, 15, 288-295. [CrossRef]

47. Zhang, Y.; Huber, D.J.; Hu, M.; Jiang, G.; Gao, Z.; Xu, X.; Jiang, Y.; Zhang, Z. Delay of postharvest browning in litchi fruit by melatonin via the enhancing of antioxidative processes and oxidation repair. J. Agric. Food Chem. 2018, 66, 7475-7484. [CrossRef]

48. Aghdam, M.S.; Luo, Z.; Li, L.; Jannatizadeh, A.; Fard, J.R.; Pirzad, F. Melatonin treatment maintains nutraceutical properties of pomegranate fruits during cold storage. Food Chem. 2020, 303, 125385. [CrossRef] 